\title{
Asymmetric Ketone Reduction by Immobilized Rhodotorula mucilaginosa
}

\author{
Hui Liu ${ }^{1}$, Wen-Di Duan ${ }^{2,3}$, Fayene Zeferino Ribeiro de Souza ${ }^{4}$, Lan Liu ${ }^{1}$ (D) \\ and Bi-Shuang Chen $1, *$ (iD \\ 1 School of Marine Sciences, Sun Yat-Sen University, Guangzhou 510275, China; \\ liuh229@mail2.sysu.edu.cn (H.L.); cesllan@mail.sysu.edu.cn (L.L.) \\ 2 Shanghai Institute of Materia Medica, Chinese Academy of Sciences, Shanghai 210203, China; \\ duanwd@mail2.sysu.edu.cn \\ 3 University of Chinese Academy of Sciences, Beijing 100049, China \\ 4 Departamento de Química, Faculdade de Ciências, UNESP, Bauru 17033-360, Brazil; \\ faylittlefay@yahoo.com.br \\ * Correspondence: chenbsh23@mail.sysu.edu.cn; Tel.: +86-20-84725459
}

Received: 29 March 2018; Accepted: 17 April 2018; Published: 19 April 2018

\begin{abstract}
In our previous study, Rhodotorula mucilaginosa (R. mucilaginosa) was selected via high throughput screening as a very active and selective whole-cell biocatalyst for the asymmetric reduction of ketones. In this study, the reduction of ketones to the desired chiral alcohols by immobilized cells of this strain was investigated. Characterization with Fourier-transform infrared (FTIR) spectroscopy and scanning electron microscopy (SEM) showed that whole R. mucilaginosa cells were successfully immobilized on support matrices composed of agar, calcium alginate, PVA-alginate and chitosan. The immobilized cells were applied to the enantioselective reduction of fourteen different aromatic ketones. Good to excellent results were achieved with $R$. mucilaginosa cells immobilized on agar and calcium alginate. The immobilized cells on the selected support matrix composed of agar exhibited a significant increase in $\mathrm{pH}$ tolerance at $\mathrm{pH} 3.5-9$ and demonstrated highly improved thermal stability compared to free cells. The cells immobilized on agar retained $90 \%$ activity after 60 days storage at $4{ }^{\circ} \mathrm{C}$ and retained almost $100 \%$ activity after 6 reuse cycles. In addition, the immobilization procedures are very simple and cause minimal pollution. These results suggest that the application of immobilized $R$. mucilaginosa can be practical on an industrial scale to produce chiral alcohols.
\end{abstract}

Keywords: biocatalyst; Rhodotorula mucilaginosa; immobilization; asymmetric reduction; stability

\section{Introduction}

Chiral alcohols are useful intermediates that are applicable for the synthesis of pharmaceuticals, flavors, aromas, agricultural chemicals and specialty materials [1]. Among the methods for their production, enantioselective ketone reduction is generally regarded as a reliable, scalable and straightforward method to obtain optically active alcohols [2,3]. Whereas traditional synthetic methods usually use toxic metals or expensive complex hydrides [4-6], enzymatic enantioselective reductions benefit from high selectivity, environmentally friendly processes and simple operations and are thus of great interest [7]. Nevertheless, biotechnological approaches are still limited in their industrial application due, in most cases, to low volumetric productivity, high cost of catalyst preparation, complex final products, and/or complicated downstream processing [8]. Much attention is needed for the development of robust biocatalysts to facilitate the performance of biocatalytic reduction 
processes, such as high substrate loads, to obtain industrial feasibility and competitiveness of preparative-scale biotransformations.

Biocatalytic processes can benefit from the habitat-related characteristics of marine enzymes, that is excellent stability and activity under extreme conditions (such as, extreme temperature, pressure, or $\mathrm{pH}$ or an organic solvent) and the unique enzyme properties of substrate specificity and affinity $[9,10]$. In our previous study, after a microbial screen, the marine fungi $R$. mucilaginosa was selected as a very active and selective whole-cell biocatalyst for the asymmetric reduction of ketones [11,12]. Although this strain has promising catalytic properties, several challenges remain before it can be used in industrial applications. In particular, its $\mathrm{pH}$ tolerance and thermostability were not perfect yet compared to those of other marine-derived biocatalysts, which limits the utilization of this strain.

To maintain the effectiveness of a biocatalyst in a certain process, it should be protected from interactions with the reaction solvent to avoid inactivation, as inactivation might halt the enzymatic reaction [13]. In this context, a range of immobilization technologies have been introduced to improve the stability of biocatalysts and assist their recovery and reusability [14]. Among the immobilized biocatalysts, purified enzymes are commonly immobilized in/on materials known as matrices, yet the immobilization of marine fungi has rarely been reported. Notably, the immobilization of whole cell biocatalysts is of interest in light of the growing number of industrial applications using biotechnological approaches in the medicinal and food industries, especially the application of methods using filamentous fungi with a large production of enzymes [15].

The present study is a continuation of our work on the use of marine-derived fungi as biocatalysts for the asymmetric reduction of ketones. The conversion of ketones to the corresponding chiral alcohols by immobilized R. mucilaginosa cells was investigated. Whole $R$. mucilaginosa cells were immobilized on support matrices composed of agar, calcium alginate, PVA-alginate and chitosan and the synthetic potential of the immobilized cells was evaluated for the enantioselective reduction of fourteen aromatic ketones of various compound classes.

\section{Results and Discussion}

Marine fungi, which are considered promising biological carriers, have been employed in many industrial sectors [16]. Recently, we investigated the use of marine-derived fungi for the reduction of aromatic ketones [10,11] and R. mucilaginosa GIM 2.157 was selected as a very active and selective whole-cell biocatalyst after a microbial screen. Whole-cell immobilization technology has attracted widespread attention for its application in several fields, such as its application for the biodegradation of mixed wastes and drug or fuel biosynthesis [17]. To develop a successful bioprocess, we immobilized R. mucilaginosa GIM 2.157 cells on various support matrices for the catalytic reduction of ketones (1a-1n) and tested the immobilized cells for recyclability and storage stability.

\subsection{Characterization of Immobilized Cells}

\subsubsection{FTIR Spectroscopy}

The immobilized and non-immobilized cells were confirmed by FTIR (Fourier transform infrared spectroscopy) and SEM (scanning electron microscopy). FTIR spectra showed the functional group of the immobilized cell matrices [18]. Scans were performed at 4000-400 $\mathrm{cm}^{-1}$ using a Hitachi 270-50 IR spectrophotometer with $\mathrm{KBr}$ discs. For the immobilization of whole cells on agar, the FTIR spectra of free cells, agar and immobilized cells are shown in Figure 1a [(a) is for free cells; (b) is for agar; (c) is for immobilized cells on agar]. Figure 1a (b) shows characteristic peaks at $3313 \mathrm{~cm}^{-1}(\mathrm{O}-\mathrm{H}$ stretching), $2911 \mathrm{~cm}^{-1}$ (C-H stretching) and $1152 \mathrm{~cm}^{-1}$ (C-O-C stretching) for the agar. The FTIR results support that the immobilization reaction occurred, as the peaks of the whole cells immobilized on agar show changes relative to the position and intensity of the characteristic peaks for native agar. The presence of additional peaks at $1742 \mathrm{~cm}^{-1}$ and $1546 \mathrm{~cm}^{-1}$ [Figure 1a (c)] confirms that immobilization reaction occurred. 
For the immobilization of whole cells on calcium alginate, the FTIR spectra of free cells, calcium alginate and immobilized cells are shown in Figure 1b [(a) is for free cells; $(d)$ is for calcium alginate; (e) is for immobilized cells on calcium alginate]. Figure $1 \mathrm{~b}$ (d) shows characteristic peaks at $3428 \mathrm{~cm}^{-1}$ (O-H trenching), $2930 \mathrm{~cm}^{-1}$ (C-H stretching), $1032 \mathrm{~cm}^{-1}$ (C-O-C stretching), $1623 \mathrm{~cm}^{-1}$ and $1419 \mathrm{~cm}^{-1}$ (-COO asymmetric and symmetric stretching) for calcium alginate. The FTIR results support that the immobilization reaction occurred, as the peaks for the whole cells immobilized on calcium alginate show changes relative to the position and intensity of the characteristic peaks for native calcium alginate]. The presence of additional peaks at $1743 \mathrm{~cm}^{-1}$ and $1548 \mathrm{~cm}^{-1}$ [Figure $1 \mathrm{~b}(\mathrm{e})$ ] confirms that the immobilization reaction occurred.

For the immobilization of whole cells on PVA-alginate, the FTIR spectra of free cells, PVA-alginate and immobilized cells are shown in Figure 1c [(a) is for free cells; (f) is for PVA-alginate; ( $\mathrm{g}$ ) is for immobilized cells on PVA-alginate]. Figure 1c (f) shows characteristic peaks at $3417 \mathrm{~cm}^{-1}$ (for O-H stretching) and $2941 \mathrm{~cm}^{-1}$ (for C-H stretching) in PVA-alginate. The FTIR results support the occurrence of the immobilization reaction, as the peaks for whole cells immobilized on PVA-alginate show changes relative to the position and intensity of the characteristic peaks for native PVA-alginate. The presence of additional peaks at $1547 \mathrm{~cm}^{-1}$ [Figure 1c (g)] confirms that the immobilization reaction occurred.

(a)

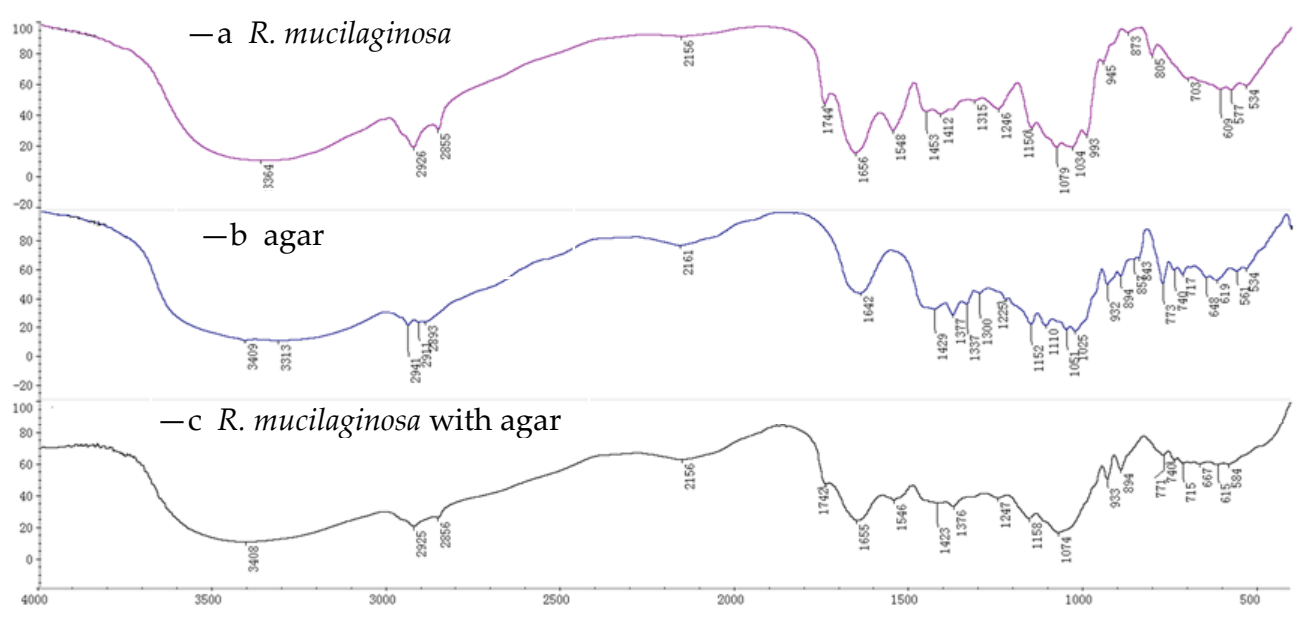

(b)

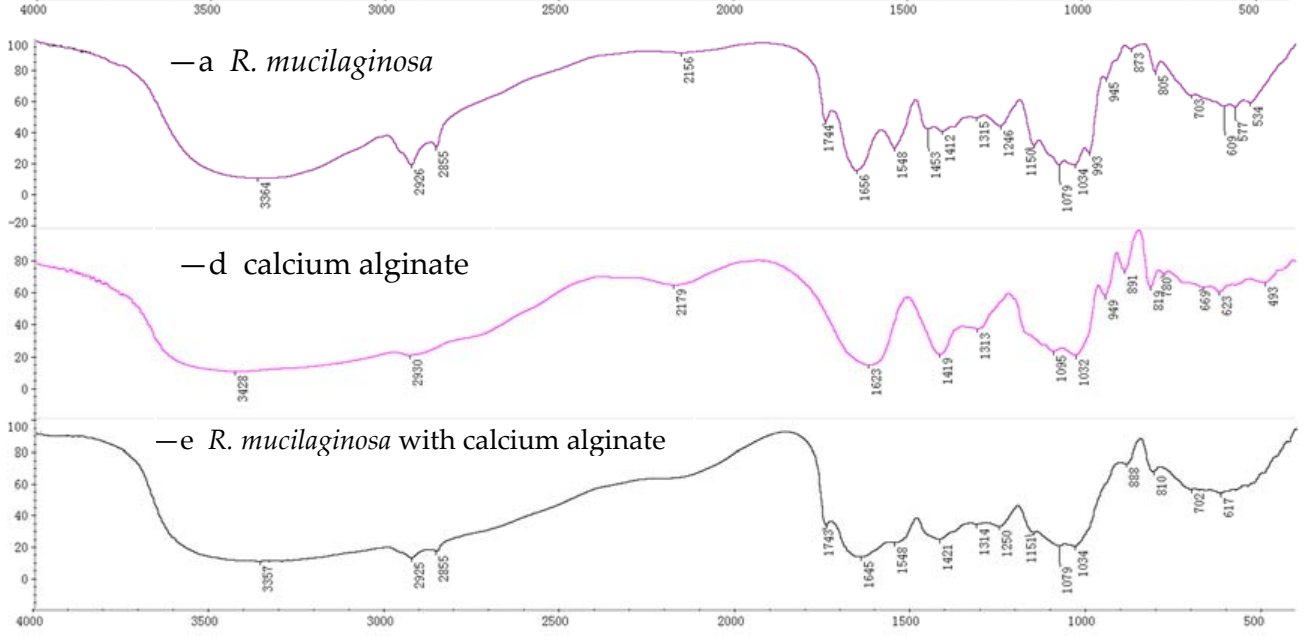

Figure 1. Cont. 
(c)

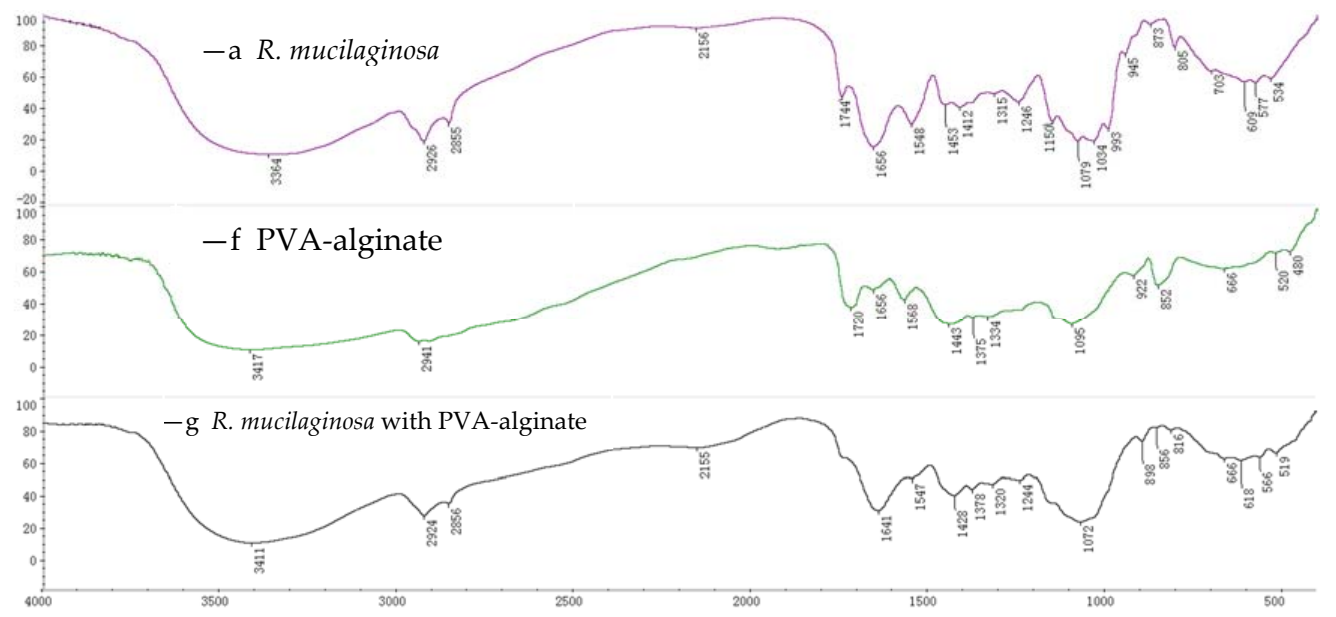

(d)

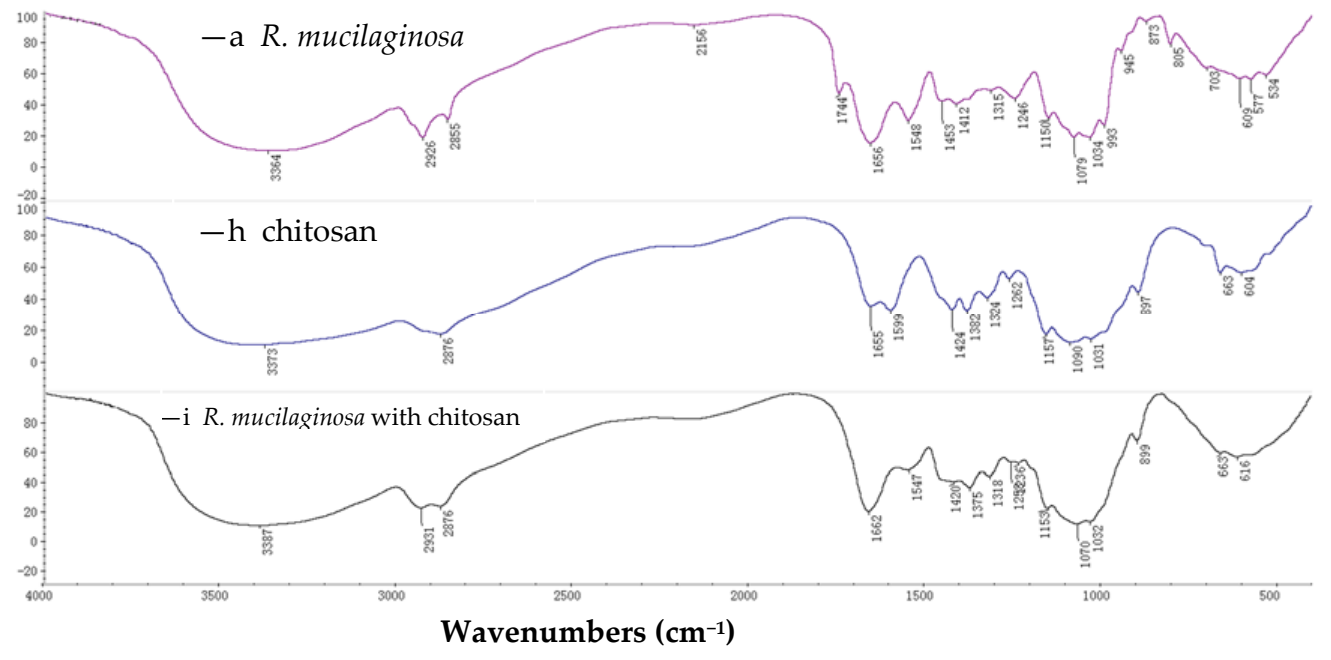

Figure 1. Fourier transform infrared (FTIR) for immobilization of R. mucilaginosa GIM 2.157 on agar (a), on calcium alginate (b), on PVA-alginate (c) and on chitosan (d): —a R. mucilaginosa; $-\mathrm{b}$ agar; $\longrightarrow \mathrm{c} R$. mucilaginosa with agar; - d calcium alginate; —e R. mucilaginosa with calcium alginate; - $\mathrm{f}$ PVA-alginate; -g R. mucilaginosa with PVA-alginate; — h chitosan; - i R. mucilaginosa with chitosan.

For the immobilization of whole cells on chitosan, the FTIR spectra of free cells, chitosan and immobilized cells on chitosan are shown in Figure 1d [(a) is for free cells; (h) is for chitosan; (i) is for immobilized cells on chitosan]. Figure $1 \mathrm{~d}\left(\mathrm{~h}\right.$ ) shows characteristic peaks at $3373 \mathrm{~cm}^{-1}$ (for $\mathrm{O}-\mathrm{H}$ stretching), $1157 \mathrm{~cm}^{-1}$ (for C-O-C stretching), $1655 \mathrm{~cm}^{-1}$ and $2876 \mathrm{~cm}^{-1}$ (for C-H stretching) for chitosan. FTIR confirmed the occurrence of the immobilization reaction, as the peaks for whole cells immobilized on calcium alginate show changes relative to the position and intensity of the characteristic peaks of native chitosan. The presence of additional peaks at $1547 \mathrm{~cm}^{-1}$ [Figure 1d (i)] confirms that the immobilization reaction occurred.

\subsubsection{SEM Spectroscopy}

The SEM images of agar, calcium alginate, PVA-alginate and chitosan immobilization are shown in Figure 2. Using simple and easy gelation technology, R. mucilaginosa GIM 2.157 cells were captured in agar microspheres and cross-linked with agar using distilled water. The SEM images for the agar immobilization are shown in Figure 2A-C. These images confirmed good immobilization of R. mucilaginosa GIM 2.157 cells on the surface due to the agar's flocculating ability and cross-linkability.

R. mucilaginosa GIM 2.157 cells were captured in calcium alginate (one of the most important immobilization matrices) microspheres and cross-linked with calcium alginate using $\mathrm{CaCl}_{2}$. The $\mathrm{SEM}$ 
images for calcium alginate immobilization are shown in Figure 2A,D,E. These images confirmed good immobilization of R. mucilaginosa GIM 2.157 cells on the surface due to calcium alginate's high mechanical strength and cross-linkability. Notably, the gelling characteristic of an alginate highly depend on its monomeric composition and sequential arrangement, which is essential for its use as an immobilization matrix [19]. The electron micrographs revealed that $4 \% \mathrm{CaCl}_{2}$ played a vital role in the formation of microspheres and that complex interactions occurred between cells and support materials.
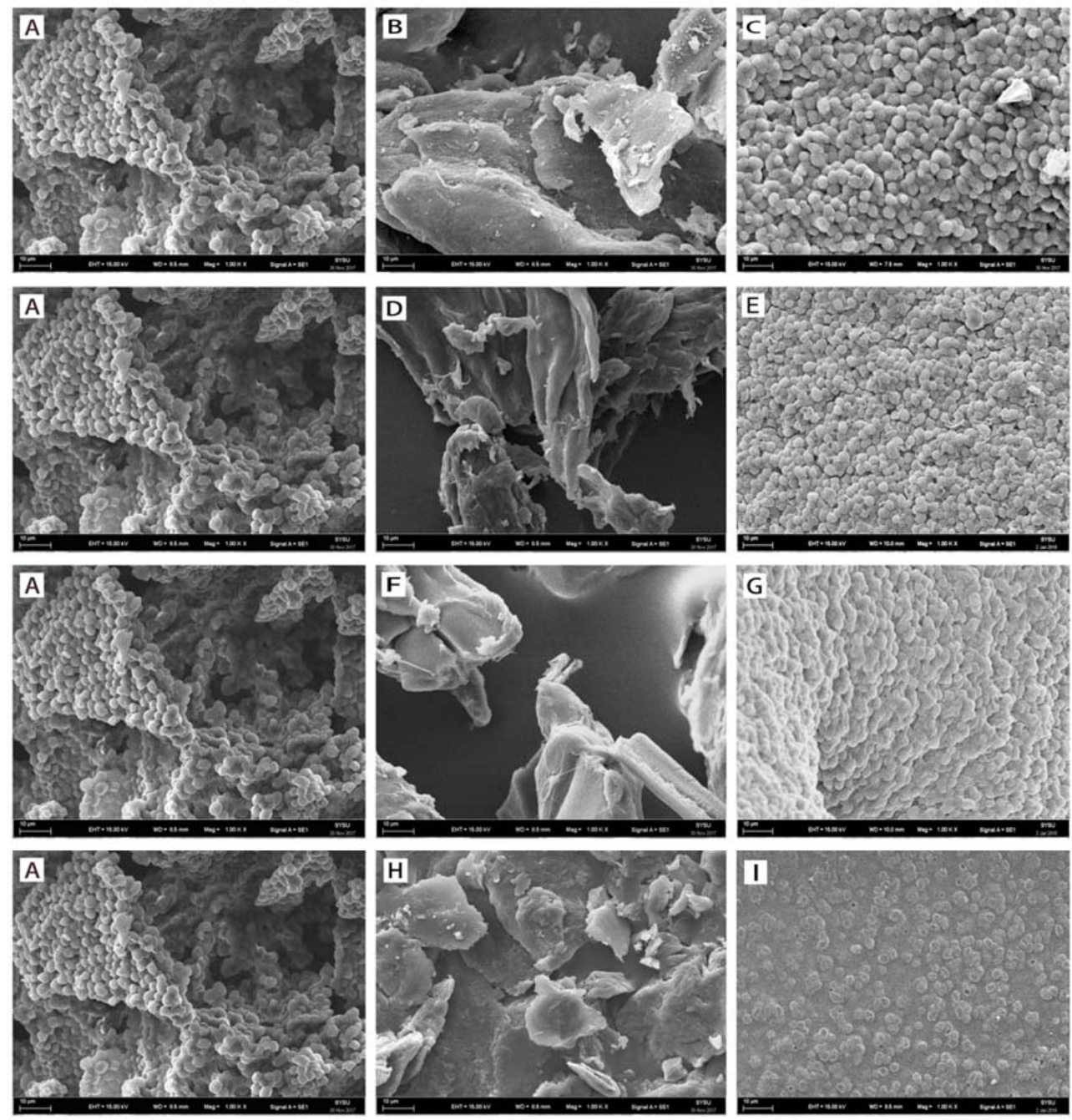

Figure 2. Scanning electron micrographs of agar, calcium alginate, PVA-alginate and chitosan beads containing $R$. mucilaginosa GIM 2.157 cells. (A) Free R. mucilaginosa GIM 2.157 cells; (B) agar; (C) R. mucilaginosa GIM 2.157 cells immobilized on agar; (D) calcium alginate; (E) R. mucilaginosa GIM 2.157 cells immobilized on calcium alginate; (F) PVA-alginate; (G) R. mucilaginosa GIM 2.157 cells immobilized on PVA-alginate; $(\mathbf{H})$ chitosan; and (I) R. mucilaginosa GIM 2.157 cells immobilized on chitosan.

The addition of calcium alginate to the mixture improved the bead characteristics by reducing the agglomeration problems of the PVA-boric acid method thus enhanced the surface characteristics of the beads [20]. R. mucilaginosa GIM 2.157 cells were captured in PVA-alginate microspheres and cross-linked with alginate-polyvinyl alcohol using boric acid. The SEM images for PVA-alginate immobilization were specifically shown in Figure 2A,F,G. These images confirmed good immobilization of $R$. mucilaginosa GIM 2.157 cells on the surface due to alginate-polyvinyl alcohol's covalent 
interactions and cross-linkability [21]. The electron micrographs also revealed that pores were made on the outer layer of the beads and the pores were almost evenly distributed and had an average size.

R. mucilaginosa GIM 2.157 cells were entrapped in chitosan surface and cross-linked using glutaraldehyde. The SEM images for chitosan immobilization are shown in Figure 2A,H,I. These images confirmed the effective immobilization of R. mucilaginosa GIM 2.157 cells on the surface because of chitosan's flocculating ability and cross-linkability [22]. Moreover, (interconnected) porous structures were observed for chitosan-immobilized R. mucilaginosa GIM 2.157 cells, suggesting that the cells have excellent immobilization performance and strong adhesion properties.

\subsection{Catalytic Activity of Immobilized Cells for the Reduction of Various Ketones}

The biocatalytic reduction of a series of prochiral ketones was attempted with $R$. mucilaginosa GIM 2.157 cells immobilized on the abovementioned support matrices (Table 1). Parallel reactions were conducted with free resting cells without the support matrices. The resting cells were also used for immobilization on agar, calcium alginate, PVA-alginate and chitosan. R. mucilaginosa GIM 2.157 cells were cultured for $24 \mathrm{~h}$. The cell mixture was centrifuged at $4000 \mathrm{rpm}\left(4^{\circ} \mathrm{C}\right)$ and washed three times with given buffer and the pellets were collected as resting cells, which were further used for immobilization reactions. All reduction reactions were performed in $10 \mathrm{~mL}$ of $\mathrm{Na}_{2} \mathrm{HPO}_{4}-\mathrm{KH}_{2} \mathrm{PO}_{4}$ buffer $(100 \mathrm{mM}, \mathrm{pH} 7.0)$ supplemented with glucose $(0.5 \mathrm{~g})$, substrates $(10 \mathrm{mM})$ and biocatalysts ( $3 \mathrm{~g}$ resting cells or $4.5 \mathrm{~g}$ immobilized cells) at $25^{\circ} \mathrm{C}$ for $24 \mathrm{~h}$. Yield and enantioselectivity were measured on a chiral HPLC (Conditions see the Experimental section). The absolute configuration of reduction products was assigned by comparison the optical rotations measured for the isolated products with those reported. The results are shown in Table 1. According to the data displayed in Table 1, the free (not immobilized) resting cells catalyzed Prelog's stereospecific reduction of ketones 1a-1h, $1 \mathrm{k}$ and 11 into the corresponding chiral alcohols with excellent yield and enantioselectivities. Notably, the immobilized cells showed slightly better activity towards substrates with substituent $-\mathrm{Cl}$ (1d, 1e and $\mathbf{1 f})$ than those with substituent $-\mathrm{Br}(\mathbf{1 a}, \mathbf{1} \mathbf{b}$ and $\mathbf{1 c})$. Regarding the mechanism, although ketone $\mathbf{1 c}$ is closely related to $\mathbf{1 f}$, the substituent $-\mathrm{Br}$ in $\mathbf{1 c}$ is a relatively poor electron-withdrawing group compared to $-\mathrm{Cl}$ in substrate $\mathbf{1 f}$. In our previous study with free resting cells [11,12], we found that substrates with electron-donating substituents inhibited the enzyme activity of $R$. mucilageinosa GIM 2.157, which might be useful to explain why the yield and ee value of $\mathbf{2 c}$ was slightly lower than those of $\mathbf{2 f}$. On the other hand, $-\mathrm{Br}$ has larger atomic radius than $-\mathrm{Cl}$, increasing the distances between substrates and immobilized cells and thus resulting in slightly lower activity (i.e., yield and $e e$ ). When resting cells were immobilized on agar, calcium alginate and PVA-alginate, they could still catalyze the reduction of assayed ketones $(\mathbf{1 a}-\mathbf{1} \mathbf{h}, \mathbf{1 k}$ and $\mathbf{1 1})$ with excellent activities; however, in some cases, the yields/enantioselectivities were slightly lower. It is possible that the access of the substrate to the carbonyl reductases must have been hindered by partial coverage of the mycelia, preventing the reaction. The R. mucilaginosa GIM 2.157 cells immobilized on agar showed slightly better activity (higher yields/ee) than those immobilized on calcium alginate and PVA-alginate. The agar bead surface likely had many porous structures, allowing more substrates and carbonyl reductases to freely access to cells inside and outside, maintaining stronger mechanical strength than other support matrices and improving the stability of the entire cellular system [23]. However, when the R. mucilaginosa GIM 2.157 cells were immobilized on chitosan, the reduction occurred in only substrates $\mathbf{1 1}$ and $\mathbf{1 k}$. This might be due to two factors: chitosan adhered strongly to the surface of the whole cells, forming a strong barrier and blocking the access of the substrate to one or more enzymes involved in the reduction [24] and the chitosan matrix completely covered the entire cellular surface so that the ketone reductase cannot be released, halting the reactions $[9,25,26]$. Interestingly, the reduction of 11 and 1k with R. mucilaginosa GIM 2.157 cells immobilized on chitosan resulted in total inversion of the configuration compared to the other biocatalysts (free cells and R. mucilaginosa GIM 2.157 cells immobilized on agar, calcium alginate and PVA-alginate). This phenomenon might occur because all carbons present in the chitosan itself were chiral, making the reaction environment chiral. In these 
chiral conditions, the configurations of the glycosidic bonds could be easily altered, which is likely related to the inversion of the configuration of reduction products $\mathbf{2} \mathbf{l}$ and $\mathbf{2 k}$. Further experiments regarding the mechanism are currently being implemented in our laboratory. Nevertheless, it can be concluded that agar was a perfect support matrix for the immobilization of $R$. mucilaginosa GIM 2.157 cells, which were used for all further studies.

Table 1. Catalytic activity of immobilized cells in the reduction of various ketones ${ }^{a}$ : the numbers indicate chemical yields of desired products, numbers within brackets indicate the enantiomeric excess values of the desired product $(\%), S / R$ within brackets indicate the absolute configuration of the desired products.

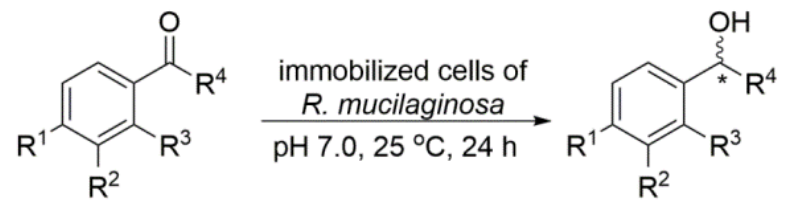

1

substrates

2<smiles>CC(=O)c1cccc(Br)c1</smiles>

$1 a$<smiles>CC(=O)c1ccccc1</smiles>

1b<smiles>CCCC(=O)c1ccccc1</smiles>

1c<smiles>CC(=O)c1ccccc1Cl</smiles>

1d<smiles>CC(=O)c1cccc(Cl)c1</smiles>

$1 \mathrm{e}$<smiles>CC(=O)c1ccc(Cl)cc1</smiles>

$1 f$

$1 \mathrm{~g}$

1h<smiles>CCc1ccc(C(C)=O)cc1</smiles><smiles>O=C(CCl)c1ccccc1</smiles><smiles>O=C(CBr)c1ccccc1</smiles><smiles>O=C(CCCl)c1ccccc1</smiles>

$1 \mathrm{~m}$<smiles>COc1ccc(C(C)=O)cc1</smiles>

1j

$1 \mathrm{k}$

11

\begin{tabular}{|c|c|c|c|c|c|}
\hline \multirow{3}{*}{ Reduction Products } & \multicolumn{5}{|c|}{ Biocatalysts } \\
\hline & \multirow{2}{*}{ Free Cells } & \multicolumn{4}{|c|}{ R. mucilaginosa Cells Immobilized on } \\
\hline & & Agar & Calcium Alginate & PVA-Alginate & Chitosan \\
\hline $2 a$ & $99(99, S)$ & $99(99, S)$ & $99(99, S)$ & $99(99, S)$ & 0 \\
\hline $2 b$ & $99(99, S)$ & $99(89,5)$ & $86(99, S)$ & $89(94, S)$ & 0 \\
\hline $2 \mathrm{c}$ & $99(99,5)$ & $73(68, S)$ & $71(19, S)$ & $51(54, S)$ & 0 \\
\hline $2 d$ & $99(99, S)$ & $99(99, S)$ & $89(99, S)$ & $97(99, S)$ & 0 \\
\hline $2 e$ & $99(99, S)$ & $99(99, S)$ & $94(89, S)$ & $99(99, S)$ & 0 \\
\hline $2 f$ & $99(99, S)$ & $94(83, S)$ & $91(94, S)$ & $59(77, S)$ & 0 \\
\hline $2 \mathrm{~g}$ & $99(99, S)$ & $99(91, S)$ & $94(97, S)$ & $75(66, S)$ & 0 \\
\hline $2 \mathrm{~h}$ & $99(99, S)$ & $99(99, S)$ & $93(99, S)$ & $94(99, S)$ & 0 \\
\hline $2 \mathbf{i}$ & 0 & 0 & 0 & 0 & 0 \\
\hline $2 j$ & 0 & 0 & 0 & 0 & 0 \\
\hline $2 k$ & $99(99, S)$ & $99(89, S)$ & $99(85, S)$ & $77(84, S)$ & $88(91, R)$ \\
\hline 21 & $99(99, R)$ & $99(73, R)$ & $99(82, R)$ & $23(21, R)$ & $72(84, S)$ \\
\hline $2 \mathrm{~m}$ & 0 & 0 & 0 & 0 & 0 \\
\hline $2 n$ & 0 & 0 & 0 & 0 & 0 \\
\hline
\end{tabular}

${ }^{a}$ Reaction conditions: $10 \mathrm{~mL} \mathrm{Na} 2 \mathrm{HPO}_{4}-\mathrm{KH}_{2} \mathrm{PO}_{4}$ buffer $(100 \mathrm{mM}, \mathrm{pH} 7.0$ ), 3 g resting cells (or $4.5 \mathrm{~g}$ immobilized cells), $10 \mathrm{mM}$ substrate, $0.5 \mathrm{~g}$ glucose, $25^{\circ} \mathrm{C}, 24 \mathrm{~h} ; 94(83, S)$ indicates $94 \%$ yield of desired (S)-selective reduction product with $83 \% e e$ for all data listed in the table above; Yield and $e e$ were determined by chiral HPLC analysis equipped with a Chiralcel AD-H chiral column; Configuration was assigned by comparing specific signs of rotation measured for isolated products to those reported in the literature. 


\subsection{Stability of Immobilized Cells on Agar}

\subsection{1. $\mathrm{pH}$ Tolerance}

It is commonly known that $\mathrm{pH}$ plays an essential role in biocatalytic reactions, that is, $\mathrm{pH}$ variation can affect the activity and selectivity of the biocatalyst. In principle, the $\mathrm{pH}$ stability of a biocatalyst can be strongly enhanced by immobilization. Thus, the effects of $\mathrm{pH}$ on the enzymatic activity of immobilized cells and free cells were both studied. Either free cells or immobilized cells were added to buffer $(10 \mathrm{~mL})$ containing $10 \mathrm{mM}$ of 1-(2-bromophenyl)ethanone 1a and glucose $(0.5 \mathrm{~g})$ at a given $\mathrm{pH}$ value between 3.5-11 (buffers at $\mathrm{pH} 3.5$ and 4.5 were prepared with citrate buffer; buffers at $\mathrm{pH}$ 5.5, 6.5, 7 and 7.5 were prepared with phosphate buffer; buffers at $\mathrm{pH} 8.5,9,10$ and 11 were prepared with Tris buffer; $100 \mathrm{mM}$ ) at $25{ }^{\circ} \mathrm{C}$ for $24 \mathrm{~h}$. As shown in Figure 3, the reaction product yield was kept above $99 \%$ within the tested range of $\mathrm{pH} 3.5-9.0$ when substrate 1a was treated with immobilized cells. As the buffer $\mathrm{pH}$ increased from 9.0 to 11.0, the activity of the immobilized cells slightly decreased and approximately $90 \%$ of its original activity was maintained. However, the catalytic activity of the free cells was much more sensitive to alkaline/acidic environments. As illustrated in Figure 3, buffer $\mathrm{pH}$ showed a significant impact on the product yield of the reaction treated with free cells. The product yield slowly increased with the increase in $\mathrm{pH}$ from 3.5 to 7.0. When buffer $\mathrm{pH}$ was further increased to alkaline ranges ( $\mathrm{pH} 7.0-11$ ), the activity of the free cells dramatically decreased to $10 \%$ of their original activity at $\mathrm{pH} 11$. Notably, within the tested buffer $\mathrm{pH}$ ranged from 3.5 to 11.0, there was only a marginal change in the product $e e$ (not shown in Figure 3). Obviously, these results suggested that R. mucilaginosa GIM 2.157 immobilization on agar beads was much more effective for improving the $\mathrm{pH}$ stability of the cells, which might be due to the unique micro-environment induced by the gel networks that may protected cells from the impact of $\mathrm{H}^{+}$ions ( $\mathrm{pH}$ variation).

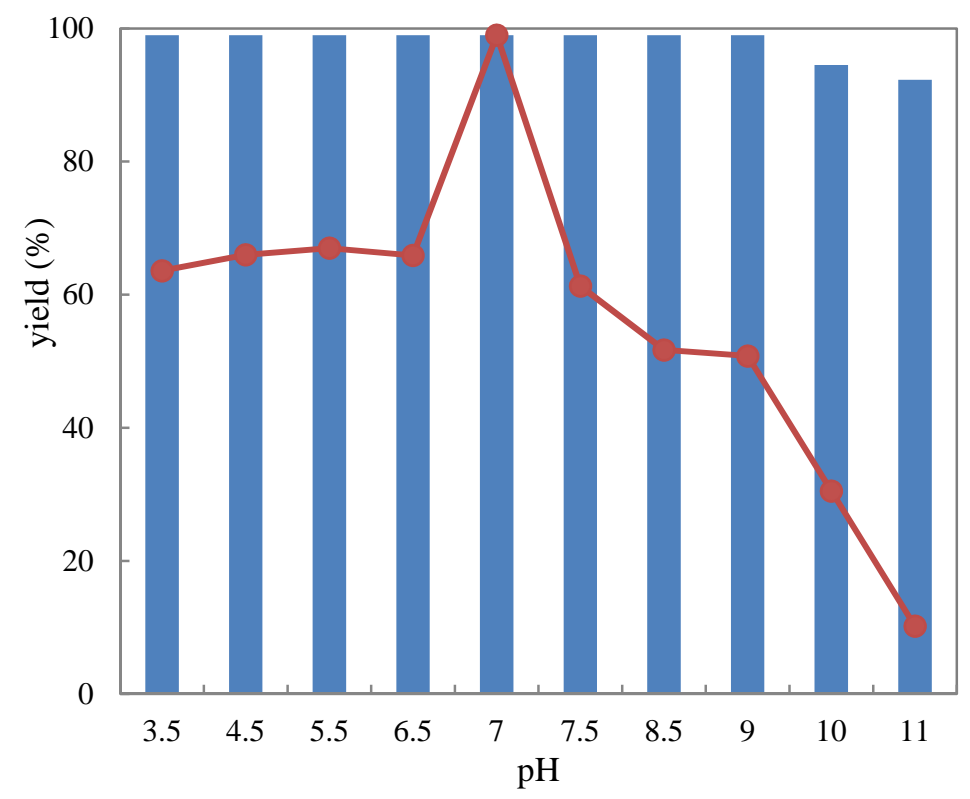

Figure 3. Optimum $\mathrm{pH}$ profile of free (represented by the dots) and agar-immobilized (striped bar) R. mucilaginosa GIM 2.157 cells for catalyzing the reduction of 1-(2-bromophenyl)ethanone (1a).

\subsubsection{Thermostability}

The immobilized cells are particularly interesting because of their stability with respect to higher temperatures, which makes them superior to the free cells. Hence, the thermostability of the immobilized R. mucilaginosa GIM 2.157 cells was characterized compared to that of the free resting cells. The immobilized cells were incubated at various temperatures $\left(30-70{ }^{\circ} \mathrm{C}\right)$ for $1 \mathrm{~h}, 3 \mathrm{~h}, 6 \mathrm{~h}, 12 \mathrm{~h}$ 
and $15 \mathrm{~h}$. The cells were added to a solution containing $10 \mathrm{~mL} \mathrm{Na} \mathrm{HPO}_{4}-\mathrm{KH}_{2} \mathrm{PO}_{4}$ buffer $(100 \mathrm{mM}$, $\mathrm{pH} 7.0)$ supplemented with substrate $1 \mathrm{a}(10 \mathrm{mM})$ and $0.5 \mathrm{~g}$ glucose. The reaction proceeded at $25^{\circ} \mathrm{C}$ for $24 \mathrm{~h}$. As shown in Figure 4, the immobilized biocatalyst showed a retention of $>99 \%$ of its original activity after $15 \mathrm{~h}$ of incubation at $30^{\circ} \mathrm{C}$ or $40{ }^{\circ} \mathrm{C}$. The immobilized cells maintained approximately $99 \%$ of their original activity after $1 \mathrm{~h}$ of incubation at $50^{\circ} \mathrm{C}$ or $60^{\circ} \mathrm{C}$. However, when the temperature was higher than $60^{\circ} \mathrm{C}$, a significant decrease was observed in the activity of the immobilized cells over a 3-h period. The immobilized cells were completely deactivated after $1 \mathrm{~h}$ at $70{ }^{\circ} \mathrm{C}$. Free cells retained $>99 \%$ of their original activity after incubation for $1 \mathrm{~h}$ at $30{ }^{\circ} \mathrm{C}$. When the temperature increasing from 30 to $60{ }^{\circ} \mathrm{C}$ led to a clear reduction in the activity $\left(27 \%\right.$ of initial activity was lost after $1 \mathrm{~h}$ at $40{ }^{\circ} \mathrm{C}$, $40 \%$ was lost after $1 \mathrm{~h}$ at $50{ }^{\circ} \mathrm{C}$ and total deactivation was observed after $1 \mathrm{~h}$ at $60^{\circ} \mathrm{C}$ ). It is clear that the immobilized cells have huge thermal stability advantages compared to the free cells.

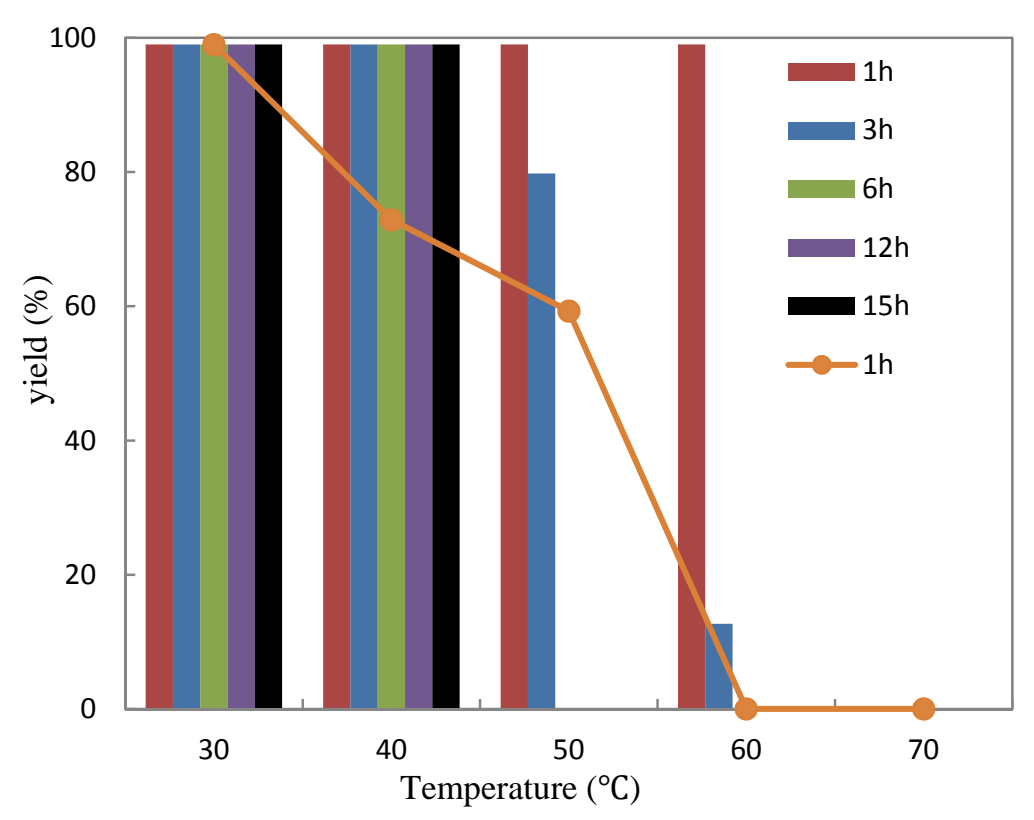

Figure 4. Thermostability of free (represented by the dots) and agar-immobilized (striped bar) R. mucilaginosa GIM 2.157 cells for catalyzing the reduction of 1-(2-bromophenyl)ethanone (1a). Cells were incubated at various temperatures and times before substrate was added to initiate reactions.

\subsubsection{Storage Stability}

One essential factor for the practical application of whole cells is their storage stability for an extended period of time. The longer the period that a biocatalyst maintains stable, the more efficient a process is. To estimate the storage stability of R. mucilaginosa GIM 2.157, free cells and cells immobilized on agar were stored at $4{ }^{\circ} \mathrm{C}$ with physiological saline $(0.85 \% \mathrm{NaCl}, w / v)$. Samples were withdrawn at various time intervals $\left(5,10,20,25,30,60\right.$ days) to determine the catalytic activity at $25^{\circ} \mathrm{C}$ using 1-(2-bromophenyl)ethanone (1a) as the substrate. As shown in Figure 5, the cells immobilized on agar showed a superior retention of activity comparing to free cells after storage for 60 days at $4{ }^{\circ} \mathrm{C}$. The cells immobilized on agar maintained approximately $95 \%$ of their original activity after storage for 60 days at $4{ }^{\circ} \mathrm{C}$, while the catalytic activity of free cells decreased to $82 \%$ after storage for 20 days at $4{ }^{\circ} \mathrm{C}$ and to $7 \%$ after storage for 60 days at $4{ }^{\circ} \mathrm{C}$. Hence, we concluded that immobilization of $R$. mucilaginosa GIM 2.157 cells on agar resulted in a biocatalyst with excellent storage properties and essential industrial application potential. 


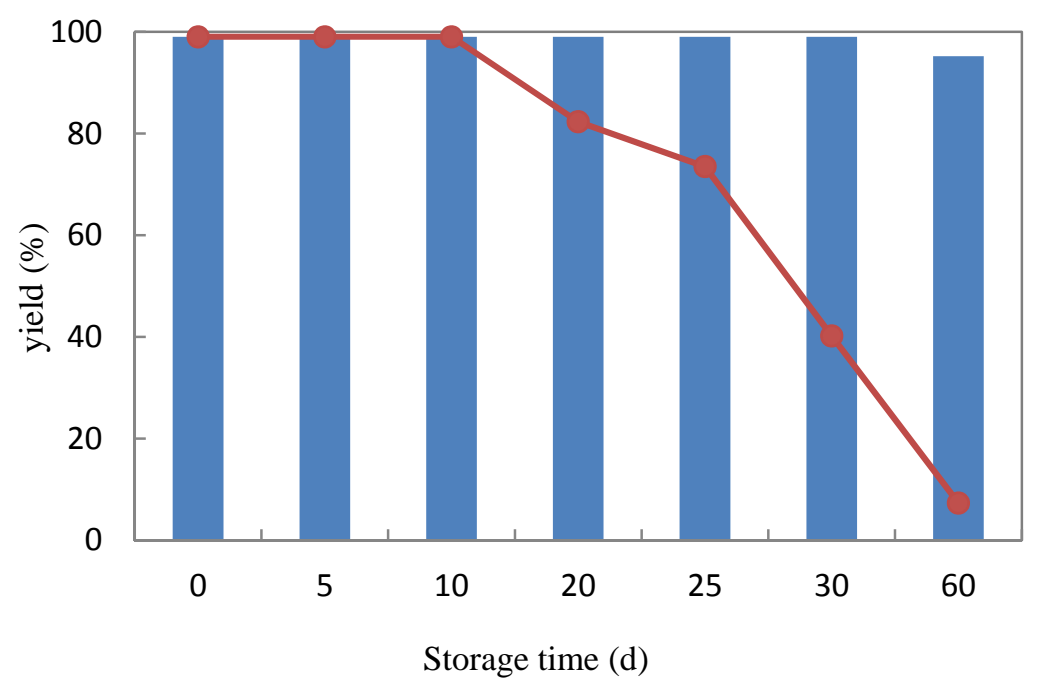

Figure 5. Storage stability of free (represented by the dots) and agar-immobilized (represented by striped bar) R. mucilaginosa GIM 2.157 cells for catalyzing the reduction of 1-(2-bromophenyl)ethanone (1a) at $4{ }^{\circ} \mathrm{C}$.

\subsubsection{Recyclability}

Recyclability is a crucial parameter for the practical application of an immobilized cell system. From a process economics point of view, if immobilized cells are stable for a higher number of cycles, then the process can be more efficiently operated. Thus, experiments were conducted to examine the recyclability of the free and agar-immobilized R. mucilaginosa GIM 2.157 cells for the reduction of 1-(2-bromophenyl)ethanone (1a) as an example. Each reaction was carried out in $10 \mathrm{~mL}$ $\mathrm{Na}_{2} \mathrm{HPO}_{4}-\mathrm{KH}_{2} \mathrm{PO}_{4}$ buffer (100 mM, pH 7.0) with $4.5 \mathrm{~g}$ immobilized cells or $3 \mathrm{~g}$ free cells, $10 \mathrm{mM}$ substrate and $0.5 \mathrm{~g}$ glucose and the reactions were shaken at $25^{\circ} \mathrm{C}$ for $23 \mathrm{~h}$. Afterwards, the cells were separated, washed two times with the same buffer $\left[\mathrm{Na}_{2} \mathrm{HPO}_{4}-\mathrm{KH}_{2} \mathrm{PO}_{4}\right.$ buffer $\left.(100 \mathrm{mM}, \mathrm{pH} 7.0)\right]$ and reused for the next batch under the same reaction conditions. R. mucilaginosa GIM 2.157 cells immobilized on agar showed high activity than free cells and completed the reduction of 1a for six cycles without significant loss of activity and selectivity. A loss of $68 \%$ of the initial activity was detected in cycle 7 , whereas almost no activity ( $3.7 \%$ yield of alcohol) was retained in cycle 8 (Figure 6). When the free cells were used, the yield dropped to $80 \%$ at cycle 4 . At cycle 5 , the activity of free cells was completely lost (corresponding to the yield of $1.4 \%$ ). Consequently, the immobilization of the R. mucilaginosa GIM 2.157 cells on agar provided a slight advantage for increasing the reusability of the cells, potentially making their implementation in commercial availability simpler and more cost effective. 


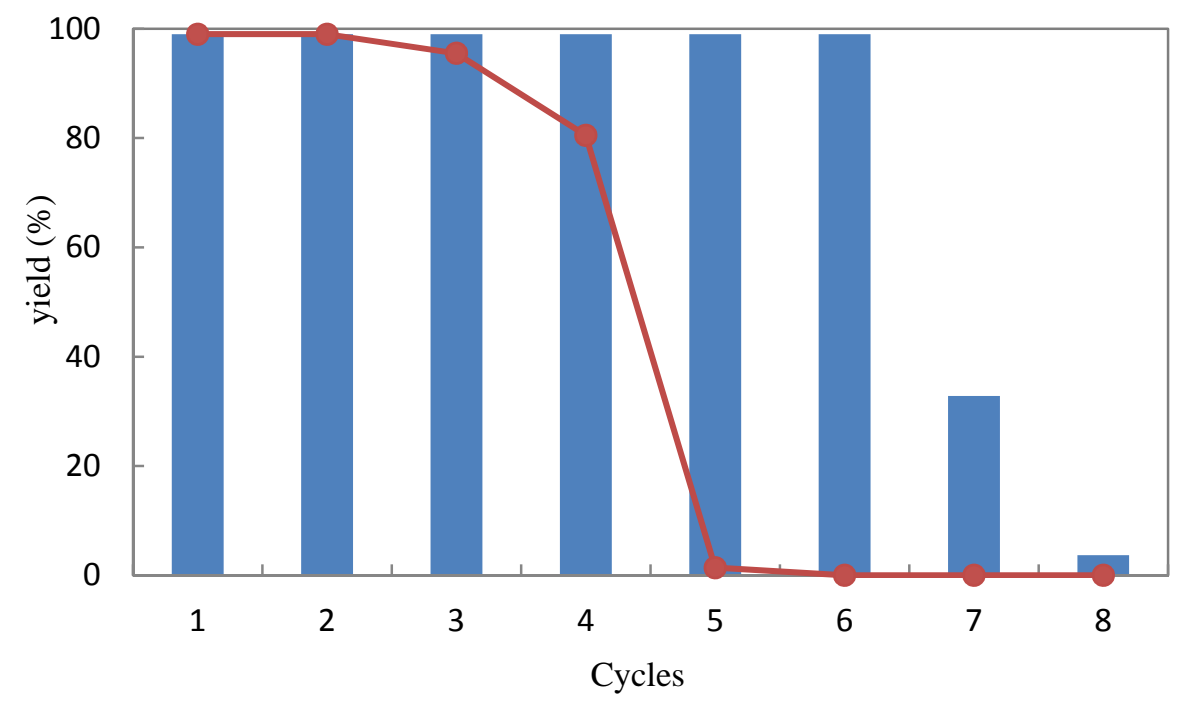

Figure 6. Repeated bioreduction of 1-(2-bromophenyl)ethanone (1a) catalyzed by free (dots) and agar-immobilized (striped bar) R. mucilaginosa GIM 2.157 cells.

\section{Materials and Methods}

\subsection{General Methods}

All substrates used in this study were obtained from Sigma-Aldrich (Schnelldorf, Denmark) and were used directly without any further purification. Fungus culture media components were purchased from Huankai Microbial (Guangzhou, China).

All NMR experiments were recorded with a Bruker Avance 500 instrument $\left({ }^{1} \mathrm{H} 500 \mathrm{MHz}\right.$ and ${ }^{13} \mathrm{C} 125 \mathrm{MHz}$ ) using $\mathrm{CDCl}_{3}$ as the solvent. Data for ${ }^{1} \mathrm{H}$ NMR are documented in terms of chemical shift $(\delta \mathrm{ppm})$, multiplicity $(\mathrm{s}=$ singlet, $\mathrm{d}=$ doublet, $\mathrm{t}=$ triplet, $\mathrm{q}=$ quartet $\mathrm{m}=$ multiplet $)$, integration, coupling constant $(\mathrm{Hz})$ and assignment. Data for ${ }^{13} \mathrm{C}$ NMR are recorded as chemical shift. Optical rotations were measured at $20^{\circ} \mathrm{C}$ on a MCP 300 (Anton Paar) (sodium D line). Column chromatography (CC) was performed with silica gel (200-300 mesh, Qingdao Marine Chemical Factory) and mixtures of petroleum ether (PE) and ethyl acetate (EtOAc) as solvents. Thin-layer chromatography (TLC) was performed on silica gel plates (Qingdao Huang Hai Chemical Group Co., G60, F-254).

Reduction products were analyzed using High Performance Liquid Chromatography (HPLC) coupled to a UV/Vis detector SPD-M10Avp (190-370 nm, Shimadzu) on a column (Daicel $4.6 \times 250 \mathrm{~mm} 5 \mathrm{~m}$ Chiralcel AD-H). The mobile phase: $n$-hexane/i-PrOH (95:5, $v / v)$; flow rate: $0.5 \mathrm{~mL} / \mathrm{min}$; column temperature: $25{ }^{\circ} \mathrm{C}$. Retention times: $11.85 \mathrm{~min}$ [1-(2-bromophenyl)ethanone (1a)], 12.71 min [(R)-1-(2-bromophenyl)ethan-1-ol ( $R$-2a)], 13.23 min [(S)-1-(2-bromophenyl)ethan-1-ol (S-2a)]; 10.66 min [1-(3-bromophenyl)ethanone (1b)], 16.45 min [(R)-1-(3-bromophenyl)ethan-1-ol $(R-2 b)], 17.39$ min [(S)-1-(3-bromophenyl)ethan-1-ol (S-2b)]; 11.21 min [1-(4-bromophenyl)ethanone (1c)], 16.83 min [(R)-1-(4-bromophenyl)ethan-1-ol ( $R$-2c)], 17.99 min [(S)-1-(4-bromophenyl)ethan-1-ol (S-2c)]; 10.71 min [1-(2-chlorophenyl)ethanone (1d)], 13.32 min [(R)-1-(2-chlorophenyl)ethan-1-ol (R-2d)], 13.98 min [(S)-1-(2-chlorophenyl)ethan-1-ol (S-2d)]; 10.49 min [1-(3-chlorophenyl)ethanone (1e)], $14.60 \mathrm{~min}$ [(R)-1-(3-chlorophenyl)ethan-1-ol (R-2e)], $16.35 \mathrm{~min}$ [(S)-1-(3-chlorophenyl)ethan-1-ol (S-2e)]; $10.78 \mathrm{~min}$ [1-(4-chlorophenyl)ethanone (1f)], 15.09 min [(R)-1-(4-chlorophenyl)ethan-1-ol (R-2f)], $16.09 \mathrm{~min}$ [(S)-1-(4-chlorophenyl)ethan-1-ol (S-2f)]; $11.46 \mathrm{~min}$ [acetophenone (1g)], $15.93 \mathrm{~min}$ [(R)-1-phenylethan-1-ol ( $R$-2g)], $17.93 \mathrm{~min}[(S)-1$-phenylethan-1-ol (S-2g)]; $10.94 \mathrm{~min}$ [propiophenone (1h)], 14.74 min [(R)-1-phenylpropan-1-ol (R-2h)], 16.49 min [(S)-1-phenylpropan-1-ol (S-2h)]; $16.75 \mathrm{~min}$ [2-chloro-1-phenylethanone $(1 \mathrm{k})], 20.98 \mathrm{~min}$ [(R)-2-chloro-1-phenylethan-1-ol $(R-2 \mathbf{k})], 24.71 \mathrm{~min}$ [(S)-2-chloro-1-phenylethan-1-ol (S-2k)]; $16.42 \mathrm{~min}$ [2-bromo-1-phenylethanone (11)], $22.33 \mathrm{~min}$ [(R)-2-bromo-1-phenylethan-1-ol ( $R$-21)], $27.39 \mathrm{~min}$ [(S)-2-bromo-1-phenylethan-1-ol (S-21)]. 
The optical rotations of reduction products were recorded as: $(S)-2 \mathbf{a},[\alpha]_{\mathrm{D}}{ }^{20}=-62.4(c$ 1.00, $\left.\mathrm{CHCl}_{3}\right) ;\left\{\right.$ Ref. [23] (S)-1-(2-bromophenyl)ethanol $\left.[\alpha]_{\mathrm{D}}{ }^{27}=-29.8\left(c 0.68, \mathrm{CHCl}_{3}\right)\right\} ;(S)-\mathbf{2 b},[\alpha]_{\mathrm{D}}{ }^{20}=-43.9$ (c 1.00, $\left.\mathrm{CHCl}_{3}\right)$; \{Ref. [24] (S)-1-(3-bromophenyl)ethanol $[\alpha]_{\mathrm{D}}{ }^{25}=-27.6$ (c 1.00, $\left.\left.\mathrm{CHCl}_{3}\right)\right\}$; (S)-2c, $[\alpha]_{\mathrm{D}}{ }^{20}=-17.3(c 1.00, \mathrm{MeOH}),\left\{\right.$ Ref. [25] (S)-1-(4-bromophenyl)ethanol $\left.[\alpha]_{\mathrm{D}}{ }^{21}=-20.6(c 1.07, \mathrm{MeOH})\right\}$; (S)-2d, $[\alpha]_{\mathrm{D}}{ }^{20}=-78.4(c 1.00, \mathrm{MeOH})$, Ref. [26] (S)-1-(2-chlorophenyl)ethanone $[\alpha]_{\mathrm{D}}{ }^{20}=-57.75(c 1.46$, $\left.\left.\mathrm{CHCl}_{3}\right)\right\} ;(S)-2 \mathbf{e},[\alpha]_{\mathrm{D}}{ }^{20}=-49.7(c 1.00, \mathrm{MeOH})$, Ref. [27] (R)-1-(3-chlorophenyl)ethanone $[\alpha]_{\mathrm{D}}{ }^{20}=+40.4$ (c 1.00, $\left.\left.\mathrm{CHCl}_{3}\right)\right\} ;(S)-2 \mathrm{f},[\alpha]_{\mathrm{D}}{ }^{20}=-66.49(c 1.00, \mathrm{MeOH})$, Ref. [27] (R)-1-(4-chlorophenyl)ethanone $\left.[\alpha]_{\mathrm{D}}^{20}=+46.1\left(c 1.70, \mathrm{CHCl}_{3}\right)\right\} ;(S)-2 \mathbf{h},[\alpha]_{\mathrm{D}}{ }^{20}=-38.5(c 1.00, \mathrm{MeOH})$, Ref. [28] (S)-1-phenylpropan-1-ol $\left.[\alpha]_{\mathrm{D}}{ }^{20}=-45.4\left(c 1.00, \mathrm{CHCl}_{3}\right)\right\} ;(S)-2 \mathbf{k},[\alpha]_{\mathrm{D}}{ }^{20}=+9.68(c 0.05, \mathrm{MeOH})$, Ref. [28] (R)-2-chloro-1phenylethanone $\left.[\alpha]_{\mathrm{D}}{ }^{20}=-5.5\left(c 1.00, \mathrm{CHCl}_{3}\right)\right\} ;(R)-2 \mathrm{l},[\alpha]_{\mathrm{D}}{ }^{20}=-16.9(c$ 0.35, MeOH), Ref. [28] (R)-2-bromo-1-phenylethanone $[\alpha]_{\mathrm{D}}{ }^{20}=-30.9\left(c\right.$ 1.00, $\left.\mathrm{CHCl}_{3}\right)$.

\subsection{Microorganism and Culture Conditions}

The marine fungus R. mucilaginosa GIM 2.157 was isolated from marine sediments collected in Guangdong Province, China and deposited at the Guangdong Culture Collection Center.

The marine fungus was cultivated on medium containing $15 \mathrm{~g}$ glucose, $5 \mathrm{~g}$ peptone, $5 \mathrm{~g}$ yeast extract, $0.5 \mathrm{~g}$ disodium hydrogen phosphate, $0.5 \mathrm{~g}$ sodium dihydrogen phosphate, $0.5 \mathrm{~g}$ magnesium sulphate and $10 \mathrm{~g}$ sodium chloride, in $1 \mathrm{~L}$ distilled water, final $\mathrm{pH}$ 7.0. The medium was autoclaved at $115^{\circ} \mathrm{C}$ for $30 \mathrm{~min}$ to get sterilized. A single colony was cut from the agar stock cultures and added to $1 \mathrm{~L}$ of medium in a 2-L Erlenmeyer flask. This culture was shaken at $28^{\circ} \mathrm{C}$ for about $48 \mathrm{~h}$. Then the cells were harvested by centrifugation at $4000 \mathrm{rpm}$ at $4{ }^{\circ} \mathrm{C}$ for $20 \mathrm{~min}$. The supernatant was discard and the cells were rinsed with a $\mathrm{Na}_{2} \mathrm{HPO}_{4}-\mathrm{KH}_{2} \mathrm{PO}_{4}$ buffer $(100 \mathrm{mM}, \mathrm{pH}$ 7.0) and centrifuged again. The supernatant was removed and the pellets were stored at $-20^{\circ} \mathrm{C}$.

\subsection{Immobilization of R. mucilaginosa GIM 2.157 by Various Matrices}

\subsubsection{On Agar}

First, $2.5 \mathrm{~g}$ wet cells were suspended in $2 \mathrm{~mL}$ distilled water and the suspensions were added to a $10-\mathrm{mL}$ sterilized agar $(5 \% \mathrm{w} / \mathrm{v})$ solution in a $50-\mathrm{mL}$ screw-capped glass vial and mixed thoroughly for $5 \mathrm{~min}$. Subsequently, the mixture was poured into the plate. The mixture was allowed to solidify and yielded a solid agar layer. The solid layer was divided into blocks $\left(3 \times 3 \times 3 \mathrm{~mm}^{3}\right)$ using a grid-cutter and then washed with distilled water and stored in phosphate buffer $(\mathrm{pH} 7,0.1 \mathrm{M})$ at $4{ }^{\circ} \mathrm{C}$.

\subsubsection{On Calcium Alginate}

First, $2.5 \mathrm{~g}$ wet cells were suspended in $5 \mathrm{~mL}$ distilled water and the suspensions were added to a 5 -mL sterilized calcium alginate $(40 \mathrm{~g} / \mathrm{L})$ solution in a $50-\mathrm{mL}$ screw-capped glass vial, stirring thoroughly for $5 \mathrm{~min}$. Subsequently, the mixture was injected dropwise into a sterilized $\mathrm{CaCl}_{2}(4 \% v / v)$ solution with a needle. After the formation of stable bead structures, the solid layers were moved to a $20-22{ }^{\circ} \mathrm{C}$ water bath for $2 \mathrm{~h}$. The spherical particles were washed thoroughly and stored in $\mathrm{CaCl}_{2}(4 \%)$ solution at $4{ }^{\circ} \mathrm{C}$.

\subsubsection{On PVA-Alginate}

First, $2.5 \mathrm{~g}$ wet cells were suspended in $5 \mathrm{~mL}$ distilled water and the suspensions were added to $5 \mathrm{~mL}$ calcium alginate $(1 \% w / v)$ in a polyvinyl alcohol $(10 \% w / v)$ solution and stirred thoroughly for $5 \mathrm{~min}$ in a 50-mL screw-capped glass vial. Subsequently, the mixture was injected dropwise into a sterilized $\mathrm{CaCl}_{2}(4 \% \mathrm{v} / \mathrm{v})$ solution by a needle. After the formation of stable bead structures, the solid layers were moved to a $20-22{ }^{\circ} \mathrm{C}$ water bath for $2 \mathrm{~h}$. These spherical particles were washed thoroughly and stored in saturated boric acid solution at $4{ }^{\circ} \mathrm{C}$. 


\subsubsection{On Chitosan}

First, $2.5 \mathrm{~g}$ wet cells were suspended in $5 \mathrm{~mL}$ distilled water and the suspensions were added to a 10-mL sterilized chitosan solution $(3 \% w / v)$ in acetic acid 3\% v/v, with thorough stirring for $5 \mathrm{~min}$ in a 50-mL screw-capped glass vial. Subsequently, this mixture was dropped with the help of a syringe into an $\mathrm{NaOH}(1 \mathrm{M}): \mathrm{MeOH}$ (80:20) solution. After $30 \mathrm{~min}$, the beads were washed thoroughly with distilled water. Thereafter, glutaraldehyde $(1 \% v / v)$ was added and stored at $4{ }^{\circ} \mathrm{C}$ for further use.

\subsection{Scanning Electron Microscopy}

For the scanning electron microscopy (SEM) analysis, the surfaces of the immobilized whole cells were washed with water to remove the non-adhering support matrix. Alcohol dehydration was performed using 10\%, 30\%, 50\%, 70\%, 90\% and 100\% ethanol; samples contacted each alcoholic solution for $15 \mathrm{~min}$. The samples were air dried at room temperature and coated with 8-10 $\mathrm{nm}$ of gold using argon ion sputtering with a Baltec MCS 010 model sputter. Finally, the metallization of the dehydrated samples was achieved and samples were observed at $15 \mathrm{kV}$ on a Joel JMS $6480 \mathrm{LV}$ computer for Scanning Electron Microscopy.

\subsection{Bioconversion of Ketones with Immobilized Cells}

The asymmetric catalytic reduction of ketones was performed in a 50-mL screw cap glass vial to prevent spillage of substrate or product. Shaking was performed in a heated ground-top shaker at $25{ }^{\circ} \mathrm{C}$ with $240 \mathrm{rpm}$. Approximately $4.5 \mathrm{~g}$ immobilized cells with agar (or with calcium alginate, PVA-alginate, chitosan) were suspended in $10 \mathrm{~mL}$ of $\mathrm{Na}_{2} \mathrm{HPO}_{4}-\mathrm{KH}_{2} \mathrm{PO}_{4}$ buffer (100 mM, pH 7.0) containing $0.5 \mathrm{~g}$ glucose and $10 \mathrm{mM}$ of aromatic ketones $(\mathbf{1 a}-\mathbf{1 n})$. For the control reaction, the setup was the same but with the addition of free cells instead of immobilized cells. Reactions were performed for $24 \mathrm{~h}$. For workup, the cells were discarded by filtration and $1 \mathrm{~mL}$ of the supernatant was saturated with $\mathrm{NaCl}$, followed by extraction with $1 \times 1 \mathrm{~mL}$ of HPLC eluent $(n$-hexane $/ i-\mathrm{PrOH}=95 / 5, v / v)$ with shaking for $5 \mathrm{~min}$. The organic layer was combined, dried over $\mathrm{Na}_{2} \mathrm{SO}_{4}$ and measured by HPLC for yield and $e e$.

\section{6. $p H$ Profile}

Reactions were performed in $10 \mathrm{~mL}$ buffer $(100 \mathrm{mM})$ containing $10 \mathrm{mM}$ 1-(2-bromophenyl) ethanone (1a), $4.5 \mathrm{~g}$ immobilized cells on agar and glucose $(0.5 \mathrm{~g})$ at $\mathrm{pH}$ values of 3.5-11 (buffers at $\mathrm{pH} 3.5$ and 4.5 were prepared with citrate buffer; buffers at $\mathrm{pH} 5.5,6.5,7$ and 7.5 were prepared with phosphate buffer; and buffers at $\mathrm{pH} 8.5,9,10$ and 11 were prepared with Tris buffer) at $25^{\circ} \mathrm{C}$ for $24 \mathrm{~h}$. Afterwards, the cells were removed by filtration and $1 \mathrm{~mL}$ of the supernatant was saturated with $\mathrm{NaCl}$, followed by extraction with $1 \times 1 \mathrm{~mL}$ of HPLC eluent $(n$-hexane $/ i$-PrOH $=95 / 5, v / v$ ) with shaking for $5 \mathrm{~min}$. The organic layer was combined, dried over $\mathrm{Na}_{2} \mathrm{SO}_{4}$ and measured using an HPLC to determine the yield and $e e$.

\subsection{Thermostability}

For thermostability studies, the immobilized cells (physiological saline) or free cells were incubated at various temperatures $\left(30-70{ }^{\circ} \mathrm{C}\right)$ for $1 \mathrm{~h}, 3 \mathrm{~h}, 6 \mathrm{~h}, 12 \mathrm{~h}$ and $15 \mathrm{~h}$ before being added to the reaction. The cells were recovered, washed thoroughly with distilled water and used for the reduction of 1-(2-bromophenyl)ethanone (1a). Reactions were performed in $10 \mathrm{~mL}$ of $\mathrm{Na}_{2} \mathrm{HPO}_{4}-\mathrm{KH}_{2} \mathrm{PO}_{4}$ buffer (100 mM, pH 7.0) containing $10 \mathrm{mM}$ of 1-(2-bromophenyl)ethanone (1a), $4.5 \mathrm{~g}$ cells immobilized on agar and glucose $(0.5 \mathrm{~g})$ at $25{ }^{\circ} \mathrm{C}$ for $24 \mathrm{~h}$. Then, the cells were discarded by filtration and $1 \mathrm{~mL}$ of supernatant was saturated with $\mathrm{NaCl}$, followed by extraction with $1 \times 1 \mathrm{~mL}$ of HPLC eluent ( $n$-hexane $/ i-\mathrm{PrOH}=95 / 5, v / v$ ) with shaking for $5 \mathrm{~min}$. The organic layer was combined, dried over $\mathrm{Na}_{2} \mathrm{SO}_{4}$ and measured using an HPLC to determine the yield and $e e$. 


\subsection{Storage Stability}

To estimate their storage stability, both free and immobilized cells were stored in $100 \mathrm{~mL}$ physiological saline $(0.85 \% \mathrm{NaCl}, w / v)$ at $4{ }^{\circ} \mathrm{C}$ for $5,10,20,25,30$ or 60 days. The cells were used to reduce 1-(2-bromophenyl)ethanone (1a). The reactions were performed in $10 \mathrm{~mL}$ of $\mathrm{Na}_{2} \mathrm{HPO}_{4}-\mathrm{KH}_{2} \mathrm{PO}_{4}$ buffer $(100 \mathrm{mM}, \mathrm{pH} 7.0)$ containing $10 \mathrm{mM}$ of 1-(2-bromophenyl)ethanone (1a), $4.5 \mathrm{~g}$ cells immobilized on agar and glucose $(0.5 \mathrm{~g})$ at $25{ }^{\circ} \mathrm{C}$ for $24 \mathrm{~h}$. Then, the cells were discarded by filtration and $1 \mathrm{~mL}$ of the supernatant was saturated with $\mathrm{NaCl}$ followed by extraction with $1 \times 1 \mathrm{~mL}$ of HPLC eluent ( $n$-hexane $/ i-\mathrm{PrOH}=95 / 5, v / v$ ) with shaking for $5 \mathrm{~min}$. The organic layer was combined, dried over $\mathrm{Na}_{2} \mathrm{SO}_{4}$ and measured using an HPLC to determine the yield and $e e$.

\subsection{Reusability}

For recyclability studies, reactions were performed with substrate $1 \mathrm{a}(10 \mathrm{mM})$ in $10 \mathrm{~mL}$ of $\mathrm{Na}_{2} \mathrm{HPO}_{4}-\mathrm{KH}_{2} \mathrm{PO}_{4}$ buffer (100 mM, pH 7.0) and $4.5 \mathrm{~g}$ R. mucilaginosa GIM 2.157 cells immobilized on agar at $25{ }^{\circ} \mathrm{C}$ for $23 \mathrm{~h}$. At the end of the reaction, the cells were centrifuged at $4000 \mathrm{rpm}$ for $20 \mathrm{~min}$ to separate them from the reaction mixture, washed with $\mathrm{Na}_{2} \mathrm{HPO}_{4}-\mathrm{KH}_{2} \mathrm{PO}_{4}$ buffer (100 mM, $\mathrm{pH} 7.0$ ) and suspended in $10 \mathrm{~mL}$ of the same buffer containing the same substrate. The reaction mixture ( $1 \mathrm{~mL}$ of supernatant separated from cells) was saturated with $\mathrm{NaCl}$ and extracted with $1 \mathrm{~mL}(\times 2)$ of HPLC eluents ( $n$-hexane $/ i-\mathrm{PrOH}=95 / 5, v / v)$ while being shaken for $5 \mathrm{~min}$. The organic phases were combined, dried over $\mathrm{Na}_{2} \mathrm{SO}_{4}$ and crude samples were analyzed using HPLC to determine the yield and $e e$.

\section{Conclusions}

In this study, we reported the immobilization of whole mycelia of a selected strain of marine-derived R. mucilaginosa GIM 2.157 on agar, calcium alginate, PVA-alginate and chitosan as support matrices. The successful immobilization was confirmed by FTIR and SEM. The immobilized cells showed a potential for the asymmetric reduction of various ketones, depending on the support matrix. It was shown that agar is a highly effective material for the entrapment of $R$. mucilaginosa GIM 2.157 cells in terms of the catalytic activity of the cells for the asymmetric reduction of ketones. The cells immobilized on agar maintained activities and selectivities comparable to those of free cells. The free cells exhibited an optimum activity at $\mathrm{pH}$ of 7.0 and were very sensitive to alkaline or acidic environments. The cells immobilized on agar retained approximately $99 \%$ of their initial activity in the $\mathrm{pH}$ range 3.5-9, with a slight decrease at $\mathrm{pH} 10$ and 11. The cells immobilized on agar retained $>99 \%$ of their original activity after incubation for $1 \mathrm{~h}$ at $60{ }^{\circ} \mathrm{C}$, while the activity of the free cells decreased to $70 \%$ after incubation for $1 \mathrm{~h}$ at $40{ }^{\circ} \mathrm{C}$. The storage stability of the R. mucilaginosa GIM 2.157 strain was greatly enhance by immobilization on agar. The agar-immobilized cells maintained approximately $95 \%$ of their original activity after storage at $4{ }^{\circ} \mathrm{C}$ for 60 days, while the catalytic activity of free cells decreased to $82 \%$ after storage at $4{ }^{\circ} \mathrm{C}$ for 20 days and to $7 \%$ after storage at $4{ }^{\circ} \mathrm{C}$ for 60 days. The immobilized cells on agar could be reused for 6 cycles without significant loss of activity, while free cells began to lose their activity at cycle 4 . As a result, the $R$. mucilaginosa GIM 2.157 cells immobilized on agar are highly practical for the enantioselective preparation of chiral alcohols.

Acknowledgments: This study was funded by the Natural Science Foundation of Guangdong Province (Grant No. 2017A030310232), the National Natural Science Foundation of China (Grant No. 41706148), the Basic Research Program of Sun Yat-Sen University (Grant No. 17lgpy58) and the National Science and Technology Major Project of the Ministry of Science and Technology of China (2018ZX09735010).

Author Contributions: Bi-Shuang Chen and Fayene Zeferino Ribeiro de Souza designed the study. Bi-Shuang Chen wrote the paper. Hui Liu and Wen-Di Duan performed the experiments. Bi-Shuang Chen and Lan Liu supervised the study. All authors made substantial contributions to the discussion of data and approved the final manuscript.

Conflicts of Interest: The authors declare no conflict of interest. 


\section{References}

1. Kataoka, M.; Kita, K.; Wada, M.; Yasohara, Y.; Hasegawa, J.; Shimizu, S. Novel bioreduction system for the production of chiral alcohols. Appl. Microbiol. Biotechnol. 2003, 62, 437-445. [CrossRef] [PubMed]

2. Nealon, C.M.; Musa, M.M.; Patel, J.M.; Phillips, R.S. Controlling substrate specificity and stereospecificity of alcohol dehydrogenases. ACS Catal. 2015, 2, 2100-2114. [CrossRef]

3. Zhang, R.; Xu, Y.; Xiao, R. Redesigning alcohol dehydrogenases/reductases for more efficient biosynthesis of enantiopure isomers. Biotechnol. Adv. 2015, 33, 1671-1684. [CrossRef] [PubMed]

4. Gyarmati, J.; Hajdu, C.; Dinya, Z.; Micskei, K.; Pályi, G. Asymmetric induction by amino acid ligands in chromium(II)-assisted reduction of ketones. J. Organomet. Chem. 1999, 586, 106-109. [CrossRef]

5. Micskei, K.; Holczknecht, O.; Hajdu, C.; Patonay, T.; Marchis, V.; Meo, M.; Zucchi, C.; Pályi, G. Asymmetric synthesis of amino acids by $\mathrm{Cr}(\mathrm{II})$ complexes of natural amino acids. J. Organomet. Chem. 2003, 682, $143-148$. [CrossRef]

6. Micskei, K.; Patonay, T.; Caglioti, L.; Pályi, G. Amino acid ligand chirality for enantioselective syntheses. Chem. Biodivers. 2010, 7, 1660-1669. [CrossRef] [PubMed]

7. Kroutil, W.; Mang, H.; Edegger, K.; Faber, K. Recent advances in the biocatalytic reduction of ketones and oxidation of sec-alcohols. Curr. Opin. Chem. Biol. 2004, 8, 120-126. [CrossRef] [PubMed]

8. Stefaan, M.A.; De, W.; Theo, S.; Hans, E.S.; Oliver, M. Biocatalytic reductions: From lab curiosity to "first choice". Acc. Chem. Res. 2007, 40, 1260-1266.

9. Rocha, L.C.; de Souza, A.L.; Filho, U.P.R.; Filho, S.P.C.; Sette, L.D.; Porto, A.L.M. Immobilization of marine fungi on silica gel, silica xerogel and chitosan for biocatalytic reduction of ketones. J. Mol. Catal. B Enzym. 2012, 84, 160-165. [CrossRef]

10. Chen, B.-S.; Liu, H.; de Souza, F.Z.R.; Liu, L. Organic solvent-tolerant marine microorganisms as catalysts for kinetic resolution of cyclic $\beta$-hydroxy ketones. Mar. Biotechnol. 2017, 19, 351-360. [CrossRef] [PubMed]

11. Liu, H.; de Souza, F.Z.R.; Liu, L.; Chen, B.-S. The use of marine-derived fungi for preparation of enantiomerically pure alcohols. Appl. Microbiol. Biotechnol. 2018, 102, 1317-1330. [CrossRef] [PubMed]

12. Liu, H.; Chen, B.-S.; de Souza, F.Z.R.; Liu, L. A comparative study on asymmetric reduction of ketones using the growing and resting cells of marine-derived fungi. Mar. Drugs 2018, 16, 62. [CrossRef] [PubMed]

13. Chen, X.-H.; Wang, X.-T.; Lou, W.-Y.; Li, Y.; Wu, H.; Zong, M.-H.; Smith, T.J.; Chen, X.-D. Immobilization of Acetobacter sp. CCTCC M209061 for efficient asymmetric reduction of ketones and biocatalyst recycling. Microb. Cell Fact. 2012, 11, 119. [CrossRef] [PubMed]

14. Lusta, K.A.; Chung, I.K.; Sul, I.W.; Park, H.S.; Shin, D.I. Immobilization of fungus Aspergillus sp. by a novel cryogel technique for production of extracellular hydrolytic enzymes. Process Biochem. 2000, 35, 1177-1182. [CrossRef]

15. Sanchez, S.; Demain, A.L. Enzymes and bioconversions of industrial, pharmaceutical, and biotechnological significance. Org. Process Res. 2011, 15, 224-230. [CrossRef]

16. Rocha, L.C.; Seleghim, M.H.R.; Comasseto, J.V.; Sette, L.D.; Porto, A.L.M. Stereoselective bioreduction of $\alpha$-azido ketones by whole cells of marine-derived fungi. Mar. Biotechnol. 2015, 17, 736-742. [CrossRef] [PubMed]

17. Zhang, Y.W.; Prabhu, P.; Lee, J.K. Alginate immobilization of recombinant Escherichia coli whole cells harboring L-arabinose isomerase for L-ribulose production. Bioprocess. Biosyst. Eng. 2010, 33, 741-748. [CrossRef] [PubMed]

18. Li, G.Y.; Huang, K.L.; Jiang, Y.R.; Ding, P. Production of (R)-mandelic acid by immobilized cells of Saccharomyces cerevisiae on chitosan carrier. Process Biochem. 2007, 42, 1465-1469. [CrossRef]

19. Idris, A.; Suzana, W. Effect of calcium alginate concentration, bead diameter, initial $\mathrm{pH}$ and temperature on lactic acid production from pineapple waste using immobilized Lactobacillus delbrueckii. Process Biochem. 2006, 41, 1117-1123. [CrossRef]

20. Wang, W.; Huang, X.J.; Cao, J.D.; Lan, P.; Wu, W. Immobilization of calcium alginate sulfates on polysulfone ultrafiltration membranes for selective adsorption of low-density lipoprotein. Acta Biomater. 2014, 10, 234-243. [CrossRef] [PubMed]

21. Cheng, Y.; Lin, H.Y.; Chen, Z.; Megharaj, M.; Naidu, R. Biodegradation of crystal violet using Burkholderia vietnamiensis C09V immobilized on PVA-calcium alginate-kaolin gel beads. Ecotoxiol. Environ. Saf. 2012, 83, 108-114. [CrossRef] [PubMed] 
22. Krajewska, B. Application of chitin- and chitosan-based materials for enzyme immobilizations: A review. Enzyme Microb. Technol. 2004, 35, 126-139. [CrossRef]

23. Nunes, M.A.P.; Vila-Real, H.; Fernandes, P.C.B.; Ribeiro, M.H.L. Immobilization of naringinase in PVA-alginate matrix using an innovative technique. Appl. Biochem. Biotechnol. 2010, 160, 2129-2147. [CrossRef] [PubMed]

24. Wu, H.; Wang, J.; Kang, X.; Wang, C.; Wang, D.; Liu, J.; Aksay, I.A.; Lin, Y. Glucose biosensor based on immobilization of glucose oxidase in platinum nanoparticles/graphene/chitosan nanocomposite film. Talanta 2009, 80, 403-406. [CrossRef] [PubMed]

25. Wu, F.C.; Tseng, R.L.; Juang, R.S. Enhanced abilities of highly swollen chitosan beads for color removal and tyrosinase immobilization. J. Hazard. Mater. 2001, 81, 167-177. [CrossRef]

26. Kumirska, J.; Czerwicka, M.; Kaczyński, Z.; Bychowska, A.; Brzozowski, K.; Thöming, J.; Stepnowski, P. Application of spectroscopic methods for structural analysis of chitin and chitosan. Mar. Drugs 2010, 8, 1567-1636. [CrossRef] [PubMed]

27. Martins, J.E.D.; Morris, D.J.; Wills, M. Asymmetric hydrogenation of ketones using $\operatorname{Ir}(\mathrm{III})$ complexes of $N$-alkyl-N'-tosyl-1,2-ethanediamine ligands. Tetrahedron Lett. 2009, 50, 688-692. [CrossRef]

28. Yearick, K.; Wolf, C. Catalytic enantioselective addition of diethylzinc to trifluoromethyl ketones. Org. Lett. 2008, 10, 4391.

(C) 2018 by the authors. Licensee MDPI, Basel, Switzerland. This article is an open access article distributed under the terms and conditions of the Creative Commons Attribution (CC BY) license (http:/ / creativecommons.org/licenses/by/4.0/). 